Brazilian Journal of Microbiology (2009) 40: 465-469

ISSN 1517-8382

\title{
FIRST DETECTION OF CANINE PARVOVIRUS TYPE 2C IN BRAZIL
}

\section{André Felipe Streck ${ }^{1}$, Carine Kunzler de Souza ${ }^{1}$, Karla Rathje Gonçalves ${ }^{1}$, Luciana Zang $^{1}$, Luciane Dubina Pinto ${ }^{1}$, Cláudio Wageck Canal ${ }^{1}$}

${ }^{1}$ Laboratório de Virologia, Faculdade de Veterinária, Universidade Federal do Rio Grande do Sul, Porto Alegre, Rio Grande do Sul, Brasil, Porto Alegre, RS, Brasil.

Submitted: October 14, 2008; Returned to authors for corrections: December 10, 2008; Approved: May 03, 2009.

\begin{abstract}
The presence of canine parvovirus type 2 (CPV-2), 2a and $2 \mathrm{~b}$ has been described in Brazil, however, the type $2 \mathrm{c}$ had not been reported until now. In the current study, seven out of nine samples from dogs with diarrhea were characterized as CPV-2c, indicating that this virus is already circulating in the Brazilian canine population.
\end{abstract}

Key words: canine parvovirus type 2c, sequence analysis, Brazil.

The canine parvovirus type $2(\mathrm{CPV}-2)$ emerged as a novel pathogen in the late 70`s (1) and rapidly spread worldwide. Within few years, the virus underwent a rapid evolution and, new antigenic types, termed CPV-2a and CPV-2b $(16,17)$, completely replaced the original type 2 (21, 24). In 2001, an antigenic variant was reported in Italy $(3,4)$. That mutant virus has an amino acid substitution (Asp-426 to Glu-426) in a residue of the capsid protein that is considered antigenically important. This mutant has also been detected in several countries $(9,15,20,26)$ and, recently, it was detected in Uruguay (20). In the last years, serological studies performed in Brazil, Rio Grande do Sul State, indicated that CPV frequently infects the canine population $(10,27)$.
However, until now, the CPV-2c has not been reported in Brazil yet.

The emergency and spread of CPV-2c is considered a sanitary threat worldwide. The monitoring of CPV field isolates has been fundamental to understand the virus epidemiology and to develop preventive measures (20). The present communication describes the first record of the CPV$2 \mathrm{c}$ detection in Brazil.

Twenty faecal samples from vaccinated and unvaccinated dogs (one to six months of age) with diarrhea were collected from January to July 2008 in private and public (Hospital de Clínicas Veterinárias) animal Hospitals located in Porto Alegre, Brazil (Table 1). Samples were

*Corresponding Author. Mailing address: Laboratório de Virologia, Faculdade de Veterinária, Universidade Federal do Rio Grande do Sul, UFRGS, Av. Bento Gonçalves, 9090, Prédio 42.602, cep 91540-000, Porto Alegre, RS, Brasil.; Phone: 5133086926 Fax: 51 33087325.; Email: afstreck@hotmail.com 
Streck, A.F. et al.

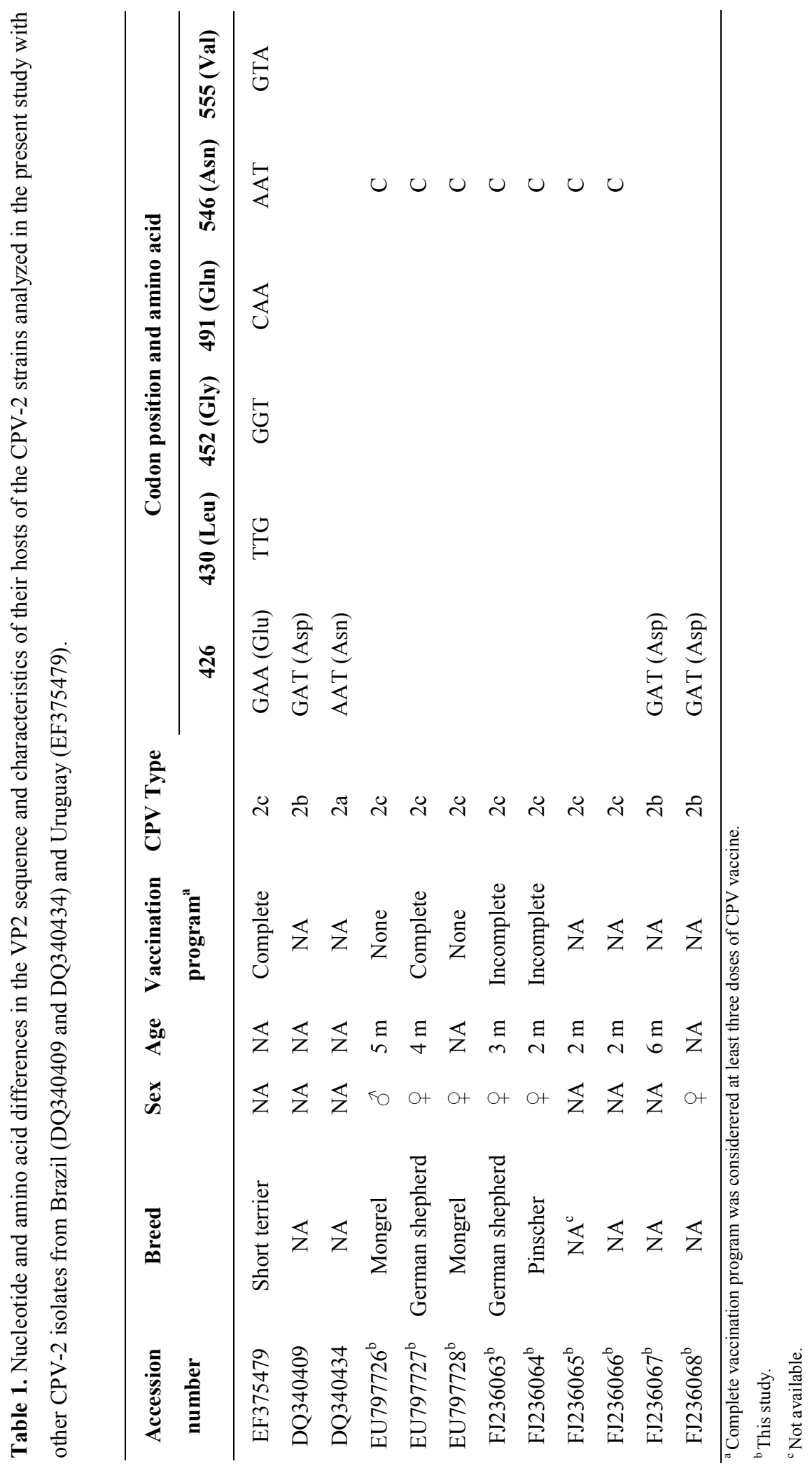


homogenized $(20 \%, w / v)$ in PBS $(\mathrm{pH}$ 7.4) frozen and defrozen three times and subsequently clarified by centrifuging at $1000 \mathrm{x} g$ for $10 \mathrm{~min}$. DNA was extracted from the supernatants using a protocol based on silica (2). PCR was carried out according previous study (3), using primer pair 555 for/555rev that amplifies a 583 base pairs (bp) fragment of the VP2 gene (position 4003 to 4585). The positive PCR products were purified with GFX DNA and Gel Band Purification (Amersham Bioscience, USA) and sequenced by using an ABI-PRISM 3100 Genetic Analyzer (Applied Biosystems, USA).

Nucleotide sequences were submitted to GenBank database (http://www.ncbi.nlm.nih.gov) and their accession numbers are displayed in Table 1. Alignments and sequence analysis were performed using Bioedit software package, version7.0.1 (http://www.mbio.ncsu.edu/BioEdit/bioedit.html) For sequence comparison, the nucleotide sequence of CPV2a (DQ340434 and EF375482), CPV-2b (DQ340409) and CPV-2c (EF375479, EF375480, EF375481, AY742942 and AY380577) were retrieved from GenBank. Nucleotide and amino acid positions in this study are referred to strain CPV2b (accession number M38245).

A single band of the expected size (583 pb) was observed in nine out of the 20 field samples. Sequencing of the amplification products revealed that all had the same nucleotide identity, with exception of two nucleotide sites (Table 1). Seven samples had the presence of a GAA codon at position 426 of the VP protein. This GAA codes for Glutamate, what characterizes the type 2c. The sequence alignment of the Brazilian 2c strains displayed high homology with the 2 a strains ( $99.2 \%$ to $99.4 \%)$, 2 b (99.4\%) and $2 \mathrm{c}(99.6 \%$ to $99.8 \%)$. One distinct nucleotide in the position 4424 (codon 546) was displayed in the seven 2c strains from Brazil but not in the strains from other countries.
This mutation ( $\mathrm{T}$ to $\mathrm{C}$ ) corresponds to a transition in the third position of the codon that did not change the amino acid sequence. The other two strains were identified as type $2 b$ and exhibited $100 \%$ nucleotide identity with one $2 \mathrm{~b}$ strain previously described in Brazil (18).

In the present study, seven out of the nine samples were type $2 c$, indicating that this type was already introduced in Brazil. In the last years, authors from many countries analyzed CPV samples to determine the circulating types, finding a high frequency of the type $2 \mathrm{c}(13,14,28)$. One study performed in Uruguay found that 24 out of the $25 \mathrm{CPV}$ strains were type 2c (20). Probably, this new viral type could have some adaptative advantage that leads it to replace the types $2 \mathrm{a}$ and $2 \mathrm{~b}(11,24)$.

Previously, the canine parvovirus types $2 \mathrm{a}$ and $2 \mathrm{~b}$ had completely replaced the type 2 worldwide. CPV appeared in Brazil around the 80's and this type change was also observed in previous studies $(6,18,19)$. The $2 \mathrm{c}$ samples analyzed in the present study presented the nucleotide $\mathrm{C}$ instead of $\mathrm{T}$ in the codon 526. This single nucleotide polymorphism was not displayed in previously reported strains and indicates that, probably, the Brazilian CPV-2c had an independent origin. However, more samples from other geographic regions of the country are necessary to have a more representative figure of the situation.

All the puppies sampled had clinical signs of gastroenteritis. Differences in clinical signs induced by distinct viral types have been reported $(5,20)$. The efficiency of the current CPV-2 vaccines against this mutant is another question that must be addressed. There is only one report showing a complete protection by an attenuated vaccine based in other CPV type against challenge by the 2c type (25). On the other hand, there are several works reporting vaccine failures when the challenge virus is from the type $2 \mathrm{c}$ 
Streck, A.F. et al.

$(7,8,20)$. Also, in the present study we cannot discuss vaccination failure because in nine positive cases only one puppy had completed the vaccination protocol.

This is the first report of the presence of CPV-2c in Brazil. The present study aims to warm the veterinarians about these new threat and possible changes among parvovirus pathology and protection afforded by the current vaccines.

\section{ACKNOWLEDGMENTS}

Financial support was provided by Conselho Nacional de Desenvolvimento Científico e Tecnológico (CNPq/Brazil), Fundação de Amparo à Pesquisa do Estado do Rio Grande do Sul (FAPERGS) and Pró-reitoria de Pesquisa (Propesq/UFRGS).

\section{RESUMO}

\section{Deteç̧ão de parvovírus canino tipo $2 \mathrm{c}$ no Brasil}

No Brasil, a presença do parvovírus canino do tipo 2 (CPV-2), 2a e 2 b já havia sido

descrita, contudo, ainda não havia sido verificada a presença do tipo 2c. No presente trabalho, sete de nove amostras de cães com diarréia foram caracterizadas como CPV-2c, indicando que este vírus já está circulando na população canina no Brasil.

Palavras-chave: parvovírus canino tipo 2c, análise se seqüências, Brasil.
1. Appel, M.J.; Scott, F.W.; Carmichael, L.E. (1979). Isolation and immunization studies of a canine parvo-like virus from dogs with hemorrhagic enteritis. Vet. Rec. 105, 156-159.

2. Boom, R.; Sol, C.J.A.; Salimans, M.M.M.; Jansen, C.L.; Wertheim-van Dillen, P.M.E.; Van der Doordaa, J. (1990). Rapid and simple method for purification of nucleic acids. J. Clin. Microbiol. 28 (3), 495-503.

3. Buonavoglia, C.; Martella, V.; Pratelli, A.; Tempesta, M.; Cavalli, A.; Buonavoglia D.; Bozzo, G.; Elia, G.; Decaro, N.; Carmichael, L. (2001). Evidence for evolution of canine parvovirus type 2 in Italy. $J$. Gen. Virol. 82, 3021-3025.

4. Buonavoglia, D.; Cavalli, A.; Pratelli, A.; Martella, V.; Greco, G.; Tempesta, M.; Buonavoglia, C. (2000). Antigenic analysis of canine parvovirus strains isolated in Italy. New Microbiol. 23, 93-96.

5. Carmichael, L.E. (2005). An annotated historical account of canine parvovirus. J. Vet. Med. B Infect. Dis. Vet. Public Health 52 (7-8), 303311.

6. Costa, A.P.; Leite, J.P.G.; Labarthe, N.V.; Cubel Garcia, R.C.N. (2005). Genomic typing of canine parvovirus circulating in the State of Rio de Janeiro, Brazil from 1995 to 2001 using Polimerase Chain Reaction assay. Vet. Res. 29, 735-743.

7. Decaro, N.; Desario, C.; Elia, G.; Martella, V.; Mari, V.; Lavazza, A.; Nardi, M.; Buonavoglia, C. (2008). Evidence for immunization failure in vaccinated adult dogs infected with canine parvovirus type $2 \mathrm{c}$. New Microbiol. 31 (1), 125-130.

8. Decaro, N.; Desario, C.; Elia, G.; Campolo, M.; Lorusso, A.; Mari, V.; Martella, V.; Buonavoglia, C. (2007). Occurrence of severe gastroenteritis in pups after canine parvovirus vaccine administration: a clinical and laboratory diagnostic dilemma. Vaccine 25 (7), 1161-1166.

9. De Ybanez, R.R.; Vela, C.; Cortés, E.; Simarro, I.; Casal, J.I. (1995). Identification of types of canine parvovirus circulating in Spain. Vet. Rec. 136, 174-175.

10. Dezengrini, R.; Weiblen, R.; Flores, E.F. (2007). Soroprevalência das infecções por parvovírus, adenovírus, coronavírus canino e pelo vírus da cinomose em cães de Santa Maria, Rio Grande do Sul, Brasil. Ciência Rural 37, 183-189.

11. Duffy, S.; Shackelton, L.A.; Holmes, E.C. (2008). Rates of evolutionary change in viruses: patterns and determinants. Nat. Rev. Genet. 9 (4), 267-276.

12. Greenwood, N.M.; Chalmers, W.S.K.; Baxendale, W.; Thompson, H. (1996). Comparison of isolates of canine parvovirus by monoclonal antibody and restriction enzyme analysis. Vet. Rec. 138, 495-496.

REFERENCES

13. Kapil, S.; Cooper, E.; Lamm, C.; Murray, B.; Rezabek, G.; Johnston, L.; Campbell, G.; Johnson, J. (2007). Canine parvovirus types 2c and 
2b circulating in North American dogs in 2006 and 2007. J. Clin. Microbiol. 45 (12), 4044-4047.

14. Martella, V.; Decaro, N.; Elia, G.; Buonavoglia, C. (2005). Surveillance activity for canine parvovirus in Italy. J. Vet. Med. B Infect. Dis. Vet. Public Health 52, 312-315.

15. Mochizuki, M.; Harasawa, R.; Nakatani, H. (1993). Antigenic and genomic variabilities among recently prevalent parvoviruses of canine and feline origin in Japan. Vet. Microbiol. 38, 1-10.

16. Parrish, C.R.; Have, P.; Foreyt, W.J.; Evermann, J.F.; Senda, M.; Carmichael, L.E. (1988). The global spread and replacement of canine parvovirus strains. J. Gen. Virol. 69, 1111-1116.

17. Parrish, C.R.; O’Connell, P.H.; Evermann, J.F.; Carmichael, L.E. (1985). Natural variation of canine parvovirus. Science 230, 10461048.

18. Pereira, C.A.; Leal, E.S.; Durigon, E.L. (2007). Selective regimenshift and demographic growth increase associated with the emergence of high-fitness variants of canine parvovirus. Infect. Genet. Evol. 7 (3), 399-409.

19. Pereira, C.A.; Monezi, T.A.; Mehnert, D.U.; D’Angelo, M.; Durigon, E.L. (2000). Molecular characterization of canine parvovirus in Brazil by polymerase chain reaction assay. Vet. Microbiol. 75, 127-133.

20. Pérez, R.; Francia, L.; Romero, V.; Maya, L.; López, I.; Hernández, M. (2007). First detection of canine parvovirus type 2c in South America. Vet. Microbiol. 124, 147-152.
21. Truyen, U. (2006). Evolution of canine parvovirus: a need for new vaccines? Vet. Microbiol. 117, 9-13.

22. Sagazio, P.; Tempesta, M.; Buonavoglia, D.; Cirone, F; Buonavoglia, C. (1998). Antigenic characterization of canine parvovirus strains isolated in Italy. J. Virol. Methods 73, 197-200.

23. Senda, M.; Parrish, C.R.; Harasawa, R.; Gamoh, K.; Muramatsu, M.; Hirayama, N.; Itoh, O. (1995). Detection by PCR of wild-type canine parvovirus which contaminates dog vaccines. J. Clin. Microbiol. 33, 110-113.

24. Shackelton, L.A.; Parrish, C.R.; Truyen, U.; Holmes, E.C. (2005). High rate of viral evolution associated with the emergence of carnivore parvovirus. PNAS 102, 379-384.

25. Spibey, N.; Greenwood, N.M.; Sutton, D.; Chalmers, W.S.; Tarpey, I. (2008). Canine parvovirus type 2 vaccine protects against virulent challenge with type 2c virus. Vet. Microbiol. 128 (1-2), 48-55.

26. Steinel, A.; Venter, E.H.; Van Vuuren, M.; Parrish, C.R.; Truyen, U. (1998). Antigenic and genetic analysis of canine parvoviruses in southern Africa. Vet. Res. 65, 239-242.

27. Strottmann, D.M.; Scortegagna, G.; Kreutz, L.C.; Barcellos, L.J.G.; Frandoloso, R.; Anziliero, D. (2008). Diagnóstico e estudo sorológico da infecção pelo parvovírus canino em cães de Passo Fundo, Rio Grande do Sul, Brasil. Ciência Rural 38, 400-405.

28. Vieira, M.J.; Silva, E.; Oliveira, J.; Vieira, A.L.; Decaro, N.; Desario, C.; Muller, A.; Carvalheira, J.; Buonavoglia, C.; Thompson, G. (2008). Canine parvovirus 2c infection in central Portugal. J. Vet. Diagn. Invest. 20, 488-491. 